\section{Pakistan's education head is asked to resign}

Pakistan's higher-education minister has stepped down after a change in government. Atta-ur-Rahman, an organic chemist at the University of Karachi, had served as head of the nation's Higher Education Commission since 2002, but his position became uncertain after a national election last month. Last week Pakistan's new president, Asif Ali Zardari, asked for Rahman's resignation. According to Rahman, his departure comes in the midst of a financial crisis that has seen the higher-education system's 27-billion-rupee (US\$340-million) budget cut by one-fifth.

Rahman is widely credited with raising the salaries of professors and boosting research spending. "A lot of good has been done," he says. "I hope the person who succeeds me will be able to continue it going forwards."

\section{Europe plans fewer free emissions allowances}

Europe's ambitious climate plan was approved last week by the European Parliament's environment committee. But a group of eastern European countries, led by Poland, threaten to block reforms to the emissions-trading system, saying that these would harm their economies.

The package of market-based and regulatory measures is intended to help reduce greenhouse-gas emissions across the European Union by $20 \%$ (compared with 1990 levels) by 2020 (see Nature 451, 504-505; 2008). The target will be increased to $30 \%$ when a new international climatechange agreement is reached.

The committee backed a number of contested changes. From 2013, the power sector will have to acquire all of its emissions allowances at auction, instead of getting them for free. Large manufacturing industries that compete internationally will be gradually phased out of free allowances from 2013 to 2020 - but the threshold for exemption will

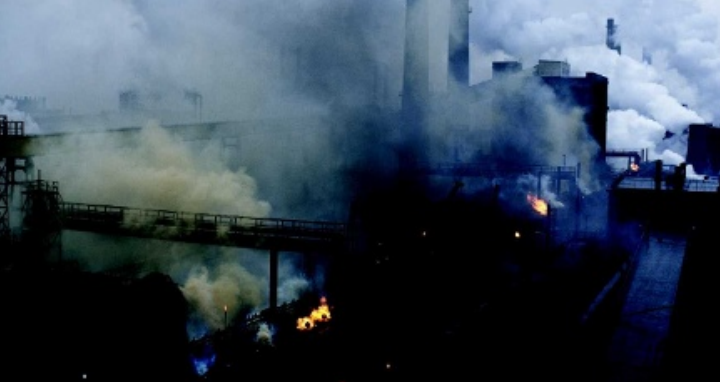

Europe's industry is facing tough emissions rules.

\section{Cassini makes successful swoop on Enceladus}

Saturn's moon Enceladus hoves into view in this image taken just 47 kilometres above its surface.

On 9 October, the Cassini spacecraft passed within about 25 kilometres of the moon on its closest approach - the nearest it has come to any moon during the mission. The trajectory took it straight through the icy plume that shoots out, geyser-like, from near the south pole of Enceladus.

This time, unlike during a close approach in March, the cosmic-dust analyser aboard Cassini worked properly and collected data on the particles of ice and water vapour that make up the geyser.

be raised from 10,000 to 25,000 tonnes of annual carbon dioxide emissions.

In response to complaints from some countries, the committee proposed that some industries will still be eligible for $100 \%$ free allowances. But the exempt sectors will only be identified after the international climate summit in Copenhagen in 2009.

\section{Harvard gift paves way for bioengineering institute}

Harvard University announced last week that it has received a $\$ 125$-million donation from business school alumnus Hansjörg Wyss to found a bioengineering institute. The donation is the largest from a single donor in the university's 372-year history.

The Wyss Institute for Biologically Inspired Engineering, to be headed by Harvard Medical School cell biologist Donald Ingber, will be located in the university's new \$1-billion science complex in the Allston neighbourhood of Boston, Massachusetts. The complex is still under construction, but will eventually also host the Harvard Stem Cell Institute, in addition to several other programmes.

The new bioengineering institute will tackle interdisciplinary projects such as repairing diseased tissues and creating selforganizing materials and devices, and will be the home of the university's syntheticbiology programme.

\section{'Manipulated' stem-cell paper faces retraction}

The University of Minnesota has asked the journal Blood to retract a high-profile paper on adult stem cells following a university investigation. The paper reported that mesenchymal stem cells isolated from adult bone marrow could generate a surprising number of tissues (M. Reyes et al. Blood $98,2615-2625 ; 2001)$, but other labs

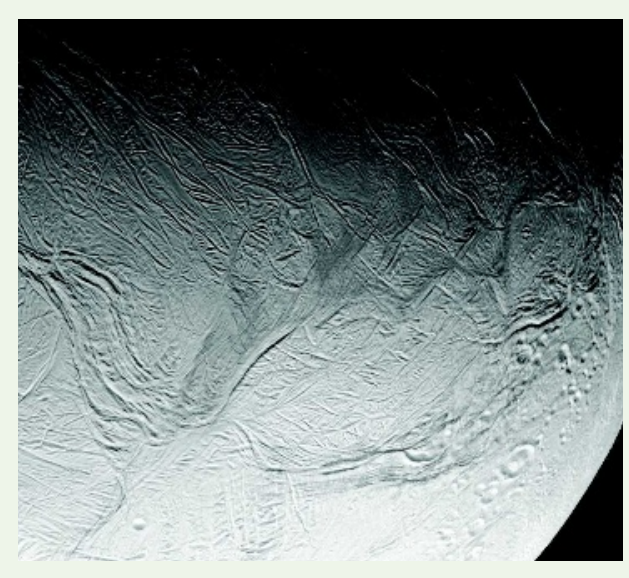

had trouble replicating that work. The investigation concluded that the paper included manipulated images.

Lead author Catherine Verfaillie, now director of the Stem Cell Institute at the Catholic University of Leuven in Belgium, was cleared of academic misconduct but blamed for insufficient oversight. That suggests the blame rests with the only other scientist under investigation, Verfaillie's graduate student Morayma Reyes, now at the University of Washington. However, the findings regarding Reyes cannot be released because of privacy laws. Reyes says that she made "honest unintentional errors".

Problematic images were also identified in a patent and in articles published by the Journal of Clinical Investigation and Nature. But the university did not find sufficient evidence of misconduct in these incidents.

The University of Washington says it may decide to investigate Reyes.

\section{UN agency warns of biofuel production implications}

The production of biofuels, which has tripled between 2002 and 2007, has significant economic, social and environmental costs. So says The State of Food and Agriculture 2008 report from the Food and Agriculture Organization of the United Nations (FAO).

Biofuels make up just over $1 \%$ of the world's transport fuel consumption, but "this figure is expected to double over the next decade", says Terri Raney, senior economist at the FAO and co-editor of the report.

The report recommends that small farmers are given help to increase the types of market at which they can sell their crops. It also backs the further development of second-generation biofuels, from woods and grasses, which are not yet commercially available but could result in fewer greenhouse-gas emissions. 